\title{
STALIŠČA STAREJŠIH DO OSKRBE NA DOMU NA DALJAVO
}

\author{
dr. Boštjan Kerbler
}

Urbanistični inštitut Republike Slovenije

Trnovski pristan 2, SI- 000 Ljubljana

e-mail: bostjan.kerbler@uirs.si

Izvirni znanstveni članek

COBISS 1.01

DOI: $10.4312 /$ dela.39.5.87-106

\section{Izvleček}

Ugotovitve različnih avtorjev kažejo, da imajo starejši ljudje po večini negativen odnos do oskrbe na domu na daljavo. Da bi spoznali stališča starejših do te storitve v Sloveniji, smo izvedli raziskavo, katere rezultati so obravnavani v tem članku. Izkazalo se je, da imajo starejši ljudje do oskrbe na domu na daljavo pozitiven odnos, kar smo pripisali učinkovitemu informiranju. Ozaveščanje potencialnih uporabnikov je zato ključnega pomena pri njenem sprejetju v družbi, vendar se je treba pri uvajanju te storitve različno odzivati na potrebe starejših v mestnem in podeželskem okolju.

Ključne besede: prebivalstvo, staranje prebivalstva, starejši ljudje, oskrba na domu na daljavo, teleoskrba

\section{ATTITUDES OF THE ELDERLY TOWARDS A REMOTE HOME CARE}

\begin{abstract}
The findings of various authors suggest that elderly people have mostly negative attitudes towards a remote home care. To determine the views of the elderly to this service in Slovenia a survey was conducted, the results of which are discussed in this article. It has turned out that elderly people have positive attitudes towards a remote home care. This was attributed to the effective information of respondents. Raising awareness of potential users is, therefore, crucial for its acceptance in a society but, the respond to the needs of the elderly in urban and rural areas should be different.
\end{abstract}

Key words: population, elderly population, ageing at home, information and communication technologies (ICT), remote home care, telecare 


\section{UVOD}

Slovenija se podobno kot druge države razvitega sveta vse bolj sooča s problemom staranja prebivalstva. Delež starejših od 65 let je v začetku leta 2013 znašal 17,1 \%, kar pomeni, da je bil že skoraj tri odstotne točke višji v primerjavi z deležem mlajšega prebivalstva (0-14 let). Kot za prihodnja desetletja kažejo Eurostatove projekcije Europop2010 (Projekcije prebivalstva EUROPOP2010 ..., 2011; Projekcije prebivalstva za Slovenijo, ..., 2011), se bo proces staranja prebivalstva v Sloveniji nadaljeval oziroma še okrepil. Delež starejših v slovenski družbi naj bi se do leta 2060 dvignil že na 31,6 \%, kar bo glede na napovedi Evropske komisije (The 2012 ageing report, 2011) nad evropskim povprečjem (29,5\%). To pomeni, da bo že skoraj vsak tretji prebivalec Slovenije star vsaj 65 let.

Slika 1: Slovenija se vse bolj sooča s problemom staranja prebivalstva - starejši ljudje na tržnici v Ljubljani (foto: B. Kerbler)

Figure 1: Slovenia is increasingly faced with the problem of an ageing population-elderly people on the market in Ljubljana (photo: B. Kerbler)

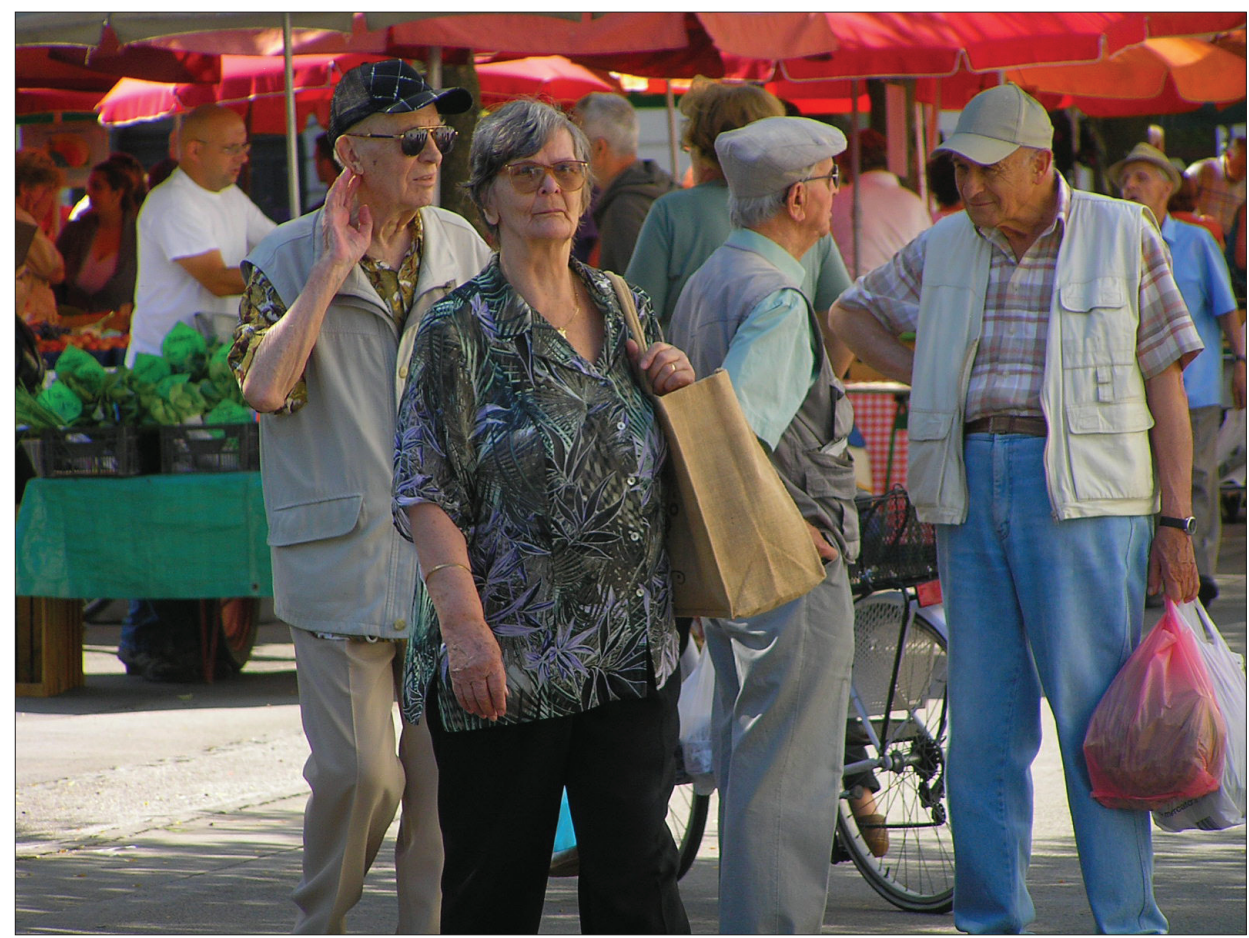

Zaradi staranja prebivalstva vse bolj narašča povpraševanje po zdravstvenih in socialnih storitvah in ustvarja vse večje stroškovne pritiske na obstoječi zdravstveni in socialni sistem. Čeprav je finančna vzdržnost teh storitev že zdaj skrb vzbujajoča, se bodo po napovedih 
Komisije Evropskih skupnosti (Akcijski načrt ..., 2007) v prihodnjih desetletjih izdatki že za pokojnine, zdravstveno varstvo in dolgotrajno oskrbo povečevali za 4-8 \% BDP, skupni stroški zdravstvenih in socialnih storitev pa naj bi se do leta 2050 potrojili. Samo za socialno varstvo naj bi v članicah Evropske unije leta 2050 delež stroškov znašal okoli 35 \% BDP (Jepsen, Leschke, 2008). V naslednjih desetletjih lahko torej utemeljeno pričakujemo, da se bo na področju zagotavljanja storitev za starejše pokazal učinek t. i. 'baby boom' povojne generacije, ki bo v vse večjem obsegu postajala uporabnik storitev za starejše.

Slika 2: Zaradi staranja prebivalstva so vse večje potrebe po zagotavljanju storitev za starejše (foto: B. Kerbler)

Figure 2: Due to an ageing population the needs to provide services for the elderly are increasing (photo: B. Kerbler)

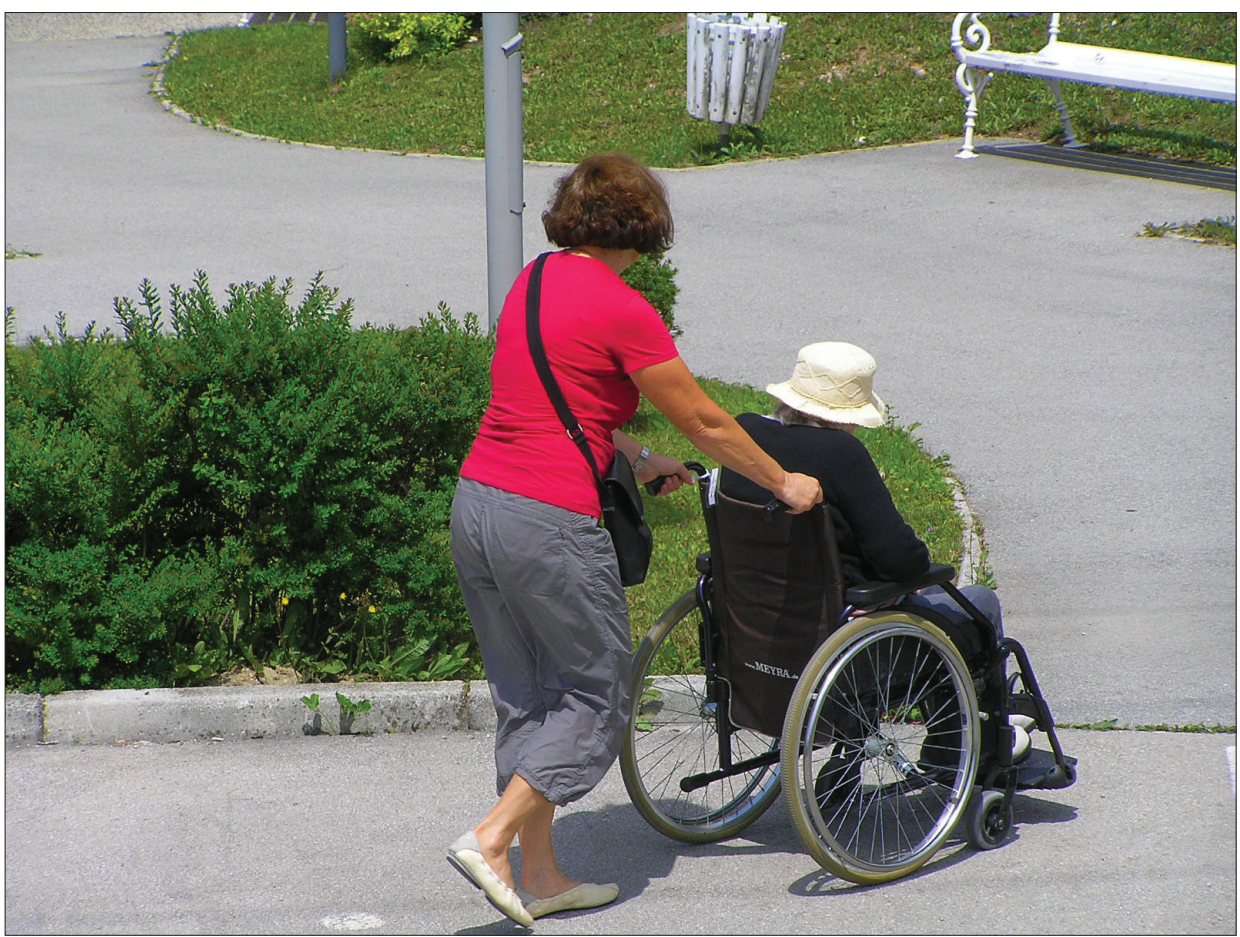

Proces staranja prebivalstva in z njim povezane težave zagotavljanja vzdržnosti zdravstvene, socialne in stanovanjske oskrbe starejših ljudi postajajo torej vse večji izziv za razvite države, tudi za Slovenijo. Nove strategije za oskrbo starajočega se prebivalstva se zato vse bolj usmerjajo k selitvi oskrbnih dejavnosti v domače okolje in s tem k podaljševanju bivanja starejših ljudi doma, kar je tudi v skladu s težnjami in željami starejših. Ti si namreč želijo ostati čim dlje časa v svojem domu, v istem, domačem bivalnem in socialnem okolju. S selitvijo oskrbne dejavnosti na domove starejših ljudi pa je treba učinkovitost izvajanja 
storitev in njihovo kakovost zagotoviti s prilagajanjem bivalnega okolja in z uvajanjem novih organizacijskih postopkov ter tehničnih in tehnoloških rešitev. Z razvojem informacijske družbe je to uresničljivo s pomočjo informacijskih in komunikacijskih tehnologij (IKT), s pomočjo katerih je lahko oskrba na domu zagotovljena na daljavo - t. i. teleoskrba (angl. telecare). Gre za sistem, pri katerem so domača bivalna okolja starejših ljudi na daljavo povezana $\mathrm{z}$ nadzornim centrom in prek njega $\mathrm{z}$ zdravstvenimi in negovalnimi centri.

Da bi ugotovili, kakšna so v Sloveniji stališča starejših ljudi do oskrbe na domu na daljavo s pomočjo IKT, smo izvedli raziskavo, katere rezultati so predstavljeni v tem članku. Izhajali smo iz domneve, ki temelji na ugotovitvah različnih avtorjev (mdr. Hanson, 2001; Marquié, Jourdan-Boddaert, Huet, 2002; Richardson, Weaver, Zorn, 2005; Lee, Phippen, 2006; Richardson, 2006) in sicer, da imajo starejši po večini negativen odnos do IKT in teleoskrbe.

\section{TEORETIČNA IZHODIŠČA}

Prve, preprostejše različice sistemov oddaljenega nadzora so bile v uporabi že v osemdesetih in v začetku devetdesetih let 20. stoletja. Šlo je za t. i. varovalno-alarmne sisteme (angl. safety alarm system), ki uporabniku omogočajo, da kadar koli ali od koder koli v svojem domu le s pritiskom na brezžično sprožilo, ki ga ima ves čas pri sebi v obliki zapestnice ali obeska, prek telefonske povezave pokliče na pomoč skrbnika ali nadzorni center in se pogovori glede pomoči (Doughty, Cameron, Garner, 1996).

Z izboljšavami IKT so se konec 90 . let prejšnjega stoletja v razvitih državah pojavile naprednejše oblike sistemov teleoskrbe, ki predstavljajo aplikativno obliko ambientalne inteligence (angl. ambient intelligence) ali inteligentnega okolja (angl. smart environment; Remagnino, Shapiro, 2007; Pecora, Cesta, 2007). Pri tem so domača okolja uporabnikov urejena po konceptu pametnih domov (angl. smart homes) in s pomočjo senzorjev, ki so vgrajeni v prostor, stalno spremljajo fizično in psihično stanje uporabnikov ter razmere v bivalnem okolju, vse podatke pa beležijo v oddaljenem informacijskem (nadzornem) centru. Če sistem zazna kakršen koli odmik od običajnih vrednosti, se sproži alarm, operater pa glede na zaznano potrebo napoti k uporabniku ustrezno pomoč. V zadnjem času so strokovnjaki razvili še inovativnejše oblike teleoskrbe, ki uporabnikom omogočajo, da so prek virtualnih medijev in spleta vključeni v širše družbeno okolje. Poimenovali so jih 'virtualna soseščina' (angl. virtual neighborhood), saj lahko uporabniki opravljajo storitve in se 'družijo' z drugimi ljudmi, ne da bi sploh zapustili svoj dom (Brownsell, Blackburn, Hawley, 2008; Brownsell in sod., 2011).

V Sloveniji je bila prva, najosnovnejša oblika varovalno-alarmnega sistema vzpostavljena leta 1992 v Ljubljani. Storitev se je imenovala Rdeči gumb oziroma Halo pomoč!, v strokovnih krogih je znana kot program Lifeline. Izvajala se je na območju občin Jesenice in Medvode ter mestnih občin Ljubljana in Kranj. V naslednjih dvajsetih letih so začeli storitev ponujati tudi drugi centri za varovanje na daljavo, in sicer v Mariboru, Celju, Kopru in Novi Gorici ter nekaj časa tudi v Slovenj Gradcu (Smolej, Nagode, Jakob Krejan, 2010). Pokrivali so območja mestnih občin in okolice, od oktobra 2011 pa je storitev uporabnikom na voljo po vsej Sloveniji. Imenuje se SOS-gumb in je dostopna prek mobilnega ali stacionarnega terminala. Glede na hiter razvoj IKT in trende drugod po svetu, 
kjer zadnjih nekaj let množično vzpostavljajo naprednejše oblike sistemov teleoskrbe (na primer v Veliki Britaniji, ZDA in na Japonskem), lahko pričakujemo, da bo prišlo do uvedbe tovrstnih inovacij tudi pri nas. Vendar pa je za uspešno uvedbo vsake inovacije v določeno družbeno okolje potrebno, da se zmožnosti, ki jih ponuja nova tehnologija, ujemajo s potrebami, z zahtevami in zmožnostmi uporabnikov (Kerbler, 2012).

Kot navaja že Rogers (1962) in za njim še številni drugi avtorji (na primer Sixsmith, Sixsmith, 2000; Levy in sod., 2003; Demiris in sod., 2004; Hanson, Percival, 2006) je prav neupoštevanje potreb in zahtev uporabnikov vzrok, da inovacije po uvedbi niso sprejete v družbi. Uporabnikov namreč ne zanimajo tehnološki vidiki inovacije, ampak predvsem njena uporabnost. Zanima jih torej 'izkušnja storitve', ne pa naprave in sistemi sami po sebi. Glavno vprašanje je torej: kaj je všeč uporabnikom in kaj 'deluje' zanje (Saranummi in sod., 2006). To je še posebej pomembno za inovativne sisteme teleoskrbe, ki temeljijo na najnaprednejših oblikah IKT in so namenjeni starejšim ljudem.

Kot namreč kažejo raziskave (Hanson, 2001; Marquié, Jourdan-Boddaert, Huet, 2002; Richardson, Weaver, Zorn, 2005; Lee, Phippen, 2006; Richardson, 2006), so starejši ljudje do IKT že na splošno nezaupljivi. Tetley, Hanson in Clarke (2001) na primer navajajo, da je ena od zaznav, ki najpogosteje odvrača starejše, ta, da je bivanje v inteligentnem okolju preveč avtomatizirano, oziroma da dojemajo tehnologijo kot zamenjavo za osebne oblike oskrbe, varstva in komunikacije, kar bi lahko imelo za posledico zmanjšanje socialne interakcije in izoliranost, ali kot svarita Wylde in Valins (1996), ustvarjanje družbe 'high-tech puščavnikov'. Po Sponseleeju in sod. (2008) to pomeni, da so starejši 'tehnofobični', torej, da jih je strah inovacij in novih tehnologij. Po Pečjaku (1998) to izhaja iz neveščosti uporabe tehnologij, po Czaji in sod. (2006) pa tudi iz pomanjkanja samozavesti in dvomov v lastne sposobnosti zaradi senzoričnih in kognitivnih pomanjkljivosti. Cheverst in sod. (2003) navedeno upravičujejo z dejstvom, da so starejši ljudje bolj konservativni in ne želijo, da bi se njihovo življenje in življenjske navade preveč spreminjali, še zlasti ne zaradi zunanjih, manj znanih, tujih dejavnikov, ki lahko posegajo v njihovo zasebnost. Po Fisku (2003) in Percival, Hansonu (2006) se starejši zlasti pri teleoskrbi bojijo izgube zasebnosti, saj imajo nelagoden občutek, da jih ves čas nekdo nadzoruje, opazuje - t. i. sindrom velikega brata (angl. big brother syndrome), kar dokazujejo raziskave Redforda in Whittena (1997), Glueckaufa in Kettersona (2004) ter Bertere in sod. (2007).

Poznavanje različnih zaznav in dojemanj naprednejših oblik teleoskrbe pri starejših bi po našem mnenju pripomoglo k uspešni(-ejši) implementaciji te storitve pri nas v prihodnje. To je še toliko pomembneje, saj uvedba varovalno-alarmnega sistema pri nas ni bila posebej uspešna. V Sloveniji je bilo namreč leta 2010, torej skoraj po dvajsetih letih njegove vzpostavitve, le 343 individualnih uporabnikov te storitve (Smolej, Nagode, Jakob Krejan, 2010), oziroma $0,1 \%$ starejših od 65 let, njihovo število pa je celo upadalo (2008: 363).

\section{METODE}

Raziskava, katere rezultate predstavljamo v tem članku, je del širše raziskave o bivanjskih navadah, željah in potrebah starejših ljudi v Sloveniji, ki smo jo izvedli v prvi polovici leta 2012. Podatke smo zbirali s pomočjo anketiranja, raziskovalni vzorec pa je 
obsegal 116 ljudi, starih 55 in več let - najmlajši je bil star 55, najstarejši 89 let. Postopek za izbor (vzorčenje) je potekal tako, da smo najprej iz seznama telefonskih naročnikov izbrali fizične osebe, nato pa smo iz seznama izbrali enako kvoto številk po statističnih regijah. Po kriteriju naključnega izbora smo poklicali na izbrane telefonske številke in vprašali, če je kdo v gospodinjstvu starejši od 55 let in če bi želel sodelovati v anketiranju. Pri tem smo pazili, da so bili izbrani anketiranci čimbolj enakomerno porazdeljeni po treh starostnih skupinah (55-64 let, 65-74 let in nad 74 let). Vzorec je obsegal 35 oseb iz prve starostne skupine (30,2\%), 42 iz druge (36,2\%) in 39 iz tretje starostne skupine $(33,6 \%)$.

Čeprav so anketiranci prebivali v vseh slovenskih statističnih regijah, nam ni uspelo zagotoviti povsem enakomerne porazdelitve anketirancev po regijah, tako da rezultati anketiranja med seboj niso primerljivi na regionalni ravni. Največ, 22 (19\%) anketirancev je bilo iz Osrednjeslovenske regije, po 14 oziroma 12,1\% iz Gorenjske in Pomurja, po 12 $(10,3 \%)$ iz Podravja in Jugovzhodne Slovenije in po 9 (7,8 \%) iz Savinjske in Obalno-kraške regije. Preostalih 20,7 \% jih je bilo iz Koroške ( 8 anketirancev), Spodnjeposavske (7), Notranjsko-kraške (4), Goriške regije (3) in Zasavja (2).

Da bi lahko rezultate anketiranja ovrednotili tudi na prostorski ravni, smo za potrebe tega prispevka anketirance na podlagi njihovih naslovov razdelili po kraju bivanja, in sicer na prebivalce mestnih in nemestnih naselij. Pri tem smo izhajali iz opredelitve teh dveh tipov naselij, kot jih je določil Statistični urad Republike Slovenije (Mestna naselja v ..., 2004). V mestnih naseljih je prebivalo 47 anketirancev (40,5\%), v nemestnih pa $69(59,5 \%)$ anketirancev. Tudi v tem primeru vzorec ni povsem enakomeren, zato smo lahko odgovore primerjali le znotraj določenega tipa naselja, ne pa med njima.

Ker smo predpostavljali, da večina anketirancev ne pozna sistema oskrbe na domu na daljavo, pri kateri so domača okolja uporabnikov urejena po konceptu pametnih domov, smo jim ga pred ugotavljanjem njihovih stališč pojasnili na preprost in razumljiv način. Njegovo delovanje smo vsem anketirancem predstavili na enak način, in sicer tako, da smo vnaprej pripravili pet kratkih 'scenarijev', v katerih smo skozi dogodke iz vsakdanjega življenja prikazali njegovo delovanje in uporabnost ter kakšna je vloga uporabnika v odnosu do tehnologij v domačem okolju.

Po predstavitvi so imeli anketiranci večinoma kar precej vprašanj, na katera smo poskušali čim bolj stvarno odgovoriti, če pa se je pojavila kakršna koli nejasnost med anketiranjem, so jo lahko prav tako izrazili. Najbolj jih je zanimalo, ali je to, kar smo jim opisali, sploh mogoče, oziroma ali res obstaja in ni le nekaj, kar bo uresničljivo šele v prihodnosti. Pri predstavitvi in odgovarjanju na takšna in podobna vprašanja se je pokazalo, da mora izpraševalec zelo dobro poznati raziskovalno področje, da mora biti vešč nazornega pojasnjevanja in da mora imeti močno sposobnost empatije. Ker je bil izpraševalec pri naši raziskavi primerno usposobljen in je imel zahtevane veščine in znanja, menimo, da so anketiranci s pomočjo opisanih metod predstavitve inovativnih oblik teleoskrbe pridobili vse potrebne informacije, na podlagi katerih so lahko objektivno izrazili svoja stališča z odgovori na naslednja vprašanja:

Če bi imeli takšno storitev pri sebi doma:

- Ali bi se zaradi tega počutili varneje in bolj samostojno, z manj skrbi glede vašega zdravja, počutja in tega, da vam nihče ne bo pomagal, če se vam doma kaj zgodi? 
- Ali menite, da bi lahko zaradi tega podaljšali bivanje v svojem domu in odšli v institucionalno varstvo kasneje ali pa vam sploh ne bi bilo treba?

- Ali bi imeli občutek, da vas ves čas nekdo opazuje in bi vam bilo neugodno, ker bi bila zaradi tega ogrožena vaša zasebnost?

- Ali menite, da bi bili zaradi tega obiski vaših sorodnikov, prijateljev, znancev manj pogosti in bi bili zato bolj osamljeni?

Za potrebe analize smo odgovore ovrednotili tako, da smo vsakemu pozitivnemu stališču do sistema oskrbe na domu na daljavo dodelili eno točko, negativnim stališčem pa nič točk. Seštevek točk za enega anketiranca je znašal od 0 do 4 , pri čemer je 0 pomenilo, da je imel anketiranec o vseh vprašanjih negativna mnenja, 4 pa, da je imel o vseh pozitivna mnenja. Ne glede na odgovore (pozitivna ali negativna stališča) smo anketirance vprašali še, ali si (kljub morebitnim negativnim stališčem) želijo imeti takšno storitev pri sebi doma. Ker se je izkazalo, da obstajajo med odgovori pomembne razlike glede na starost anketirancev, smo pri analizi nekatere rezultate prikazali in primerjali po starostnih skupinah anketirancev.

\section{REZULTATI}

Rezultati anketiranja so pokazali, da imajo starejši ljudje pozitiven odnos do teleoskrbe, kar je v nasprotju z našo domnevo. Kar 78,4 \% vprašanih je namreč odgovorilo, da si želijo imeti takšno storitev pri sebi doma, četudi do nje nimajo povsem pozitivnih stališč. Največ takšnih je bilo 'mlajših' starejših ljudi, starih od 55 do 64 let $(85,7$ \%). Delež v višjih starostnih skupinah sicer upade, vendar je kljub vsemu še vedno visok. Glede na kraj bivanja pa je več takšnih, ki si želijo storitev teleoskrbe, v nemestnih naseljih (preglednica 1). Slednje kaže, da so starejši ljudje na podeželju močno čustveno navezani na domače okolje in zaradi tradicionalnih vezi, tesnih medosebnih odnosov ter pogosto odklonilnega stališča do mestnega okolja nočejo oditi v domove za starejše, ampak si želijo čim dlje časa ostati v kraju, v katerem bivajo.

Preglednica 1: Želja po storitvi teleoskrbe pri starejših ljudeh Table 1: Desire for the telecare service among elderly

\begin{tabular}{|l|c|c|}
\hline \multirow{2}{*}{ Starostna skupina/kraj bivanja } & \multicolumn{2}{|c|}{$\begin{array}{c}\text { Želja storitvi teleoskrbe na } \\
\text { domu (delež) }\end{array}$} \\
\cline { 2 - 3 } & Da & Ne \\
\hline 55-64 let & 85,7 & 14,3 \\
\hline 65-74 let & 78,6 & 21,4 \\
\hline Nad 74 let & 71,8 & 28,2 \\
\hline Mestno naselje & 72,3 & 27,7 \\
\hline Nemestno naselje & 82,6 & 17,4 \\
\hline Skupaj & 78,4 & 21,6 \\
\hline
\end{tabular}


Kljub takšnim mnenjem je nadaljnja analiza pokazala, da imajo starejši ljudje vseeno določene pomisleke glede sistema oskrbe na domu na daljavo. Več kot polovica $(55,2 \%)$ jih je namreč izrazila vsaj eno negativno stališče. Glede na starost je bilo najmanj takšnih med mlajšimi starostniki (37,1 \%), največ pa med najstarejšimi (71,8 \%). Glede na kraj bivanja pa je za razliko od splošnega stališča do storitev teleoskrbe, manjši delež tistih, ki so izrazili pomisleke, prebivalo $\mathrm{v}$ mestnih kot $\mathrm{v}$ nemestnih naseljih (preglednica 2). To kaže, da imajo starejši na podeželju bolj zadržan odnos do inovacij, zlasti do IKT, saj so v njihovem vsakodnevnem življenju manj prisotne. Obenem to potrjuje tudi naše ugotovitve, da želijo v starosti za vsako ceno ostati v svojem domačem okolju - torej, tudi če bi morali v zameno za to v svoje življenje 'sprejeti' novo, njim neznano inovativno storitev, do katere imajo sicer pomisleke.

Preglednica 2: Negativna stališča starejših ljudi do sistema oskrbe na domu na daljavo Table 2: Negative attitudes towards remote home care among elderly

\begin{tabular}{|l|c|c|}
\hline \multirow{2}{*}{ Starostna skupina /kraj bivanja } & \multicolumn{2}{|c|}{$\begin{array}{c}\text { Delež negativnih/pozitivnih } \\
\text { stališc }\end{array}$} \\
\cline { 2 - 3 } & $\begin{array}{c}\text { Vsaj eno } \\
\text { negativno } \\
\text { stališče }\end{array}$ & $\begin{array}{c}\text { Samo } \\
\text { pozitivna } \\
\text { stališča }\end{array}$ \\
\hline 55-64 let & 37,1 & 62,9 \\
\hline 65-74 let & 54,7 & 45,2 \\
\hline Nad 74 let & 71,8 & 28,2 \\
\hline Mestno naselje & 48,9 & 51,1 \\
\hline Nemestno naselje & 59,4 & 40,6 \\
\hline Skupaj & 55,2 & 44,8 \\
\hline
\end{tabular}

Negativna stališča do nekaterih značilnosti teleoskrbe pa še ne pomenijo tudi nasprotovanje njeni uvedbi. Kot se je izkazalo, bi se ji po večini odrekli le tisti, ki glede storitve niso izrazili nobenega pozitivnega stališča, oziroma so bila njihova stališča večinoma negativna. Tisti, ki so izrazili vsaj pol ali večino pozitivnih stališč, skoraj vsi podpirajo uvedbo sistema teleoskrbe v svojih domovih (preglednica 3).

Preglednica 3: Podpora uvedbi teleoskrbe glede na stališča starejših ljudi do nje

Table 3: Support for introduction of the telecare according to the attitudes of the elderly towards this service

\begin{tabular}{|l|l|l|l|l|l|}
\hline \multirow{2}{*}{ Želja po storitvi teleoskrbe } & \multicolumn{6}{|l|}{ Delež negativnih/pozitivnih stalǐ̌č } \\
\cline { 2 - 6 } & $\mathbf{0}$ & $\mathbf{1}$ & $\mathbf{2}$ & $\mathbf{3}$ & $\mathbf{4}$ \\
\hline $\mathrm{Da}$ & 0,0 & 0,0 & 84,2 & 95,8 & 100,0 \\
\hline $\mathrm{Ne}$ & 100,0 & 100,0 & 15,8 & 4,2 & 0,0 \\
\hline
\end{tabular}

Opomba: 0 = samo negativna stališča; 1 = eno pozitivno, tri negativna stališča; 2 = po dve pozitivni in negativni stališči; 3 = tri pozitivna in eno negativno stališče; $4=v$ sa pozitivna stališča 
Največ pomislekov imajo starejši ljudje glede podaljšanja bivanja v svojem domu in odhodu v domove za starejše. Polovica jih namreč ne verjame, da bi lahko sistem teleoskrbe to res omogočil. Anketiranci so o tem izrazili tudi svoja mnenja:

»Dokler bom lahko hodil, bom že lahko, ampak ko me noge ne bodo več nesle, pa bom vseeno moral v dom. Doma me nobeden ne bo mogel 'rihtat', tudi če bi imel vse te 'mašine'." (moški, 74 let)

»Sosedo je lani možganska kap. Tako iz danes na jutri. Pa prej nikoli ni imela kakšnih težav. Kaj bi ji koristila zdaj vsa ta tehnologija? Je nepokretna. Zdaj ji hčerka vse 'rihta'. Pravi, da jo bodo dali v dom, ker ne zmore več vsega.« (ženska, 68 let)

»Jaz si želim, da bi lahko čim bolj dolgo ostala tu. Samo ne verjamem, da bom lahko. Tudi če bi imela tako 'porihtano', kot Vi pravite. Ko te enkrat začne pamet zapuščati /.../ takrat te morajo drugi 'merkat', saj sploh ne veš vě́, kaj delaš. Dokler pa si pri zdravi pameti, pa tako ali tako lahko vse delaš in normalno živiš. " (ženska, 78 let)

»Moja mama je živela sama $v$ hiši. Potem pa se ji je začelo vrteti in je večkrat padla. Enkrat je pol dneva ležala, pa se ni mogla pobrati, jaz sem bila v službi. No, takrat bi najbrž prišlo prav, da bi se sprožil kak alarm. Ko pa je postajalo to vse bolj pogosto, nas je bilo vedno bolj strah. Tudi če bi imeli take naprave $v$ hiši, ne bi mogla več sama živeti. Najprej sem jo vzela k sebi, potem pa je dobila v domu." (ženska, 57 let)

Podrobnejša analiza je pokazala, da se delež tistih, ki menijo, da teleoskrba ne bi pripomogla k podaljšanju bivanja doma in kasnejšemu odhodu v domsko oskrbo, s starostjo povečuje (preglednica 4). Medtem ko je tako mislečih 'mlajših' starejših ljudi 31,4 \%, se pri starih ljudeh (nad 74 let) delež dvigne na 71,8 \%. Razlog bi lahko bil, da stari ljudje izhajajo iz izkušenj svojih vrstnikov, pri katerih se je zdravstveno stanje naenkrat poslabšalo in zato niso bili več sposobni živeti samostojno. Iz tega sklepajo, da se lahko njim zgodi podobno. Po drugi strani 'mlajši' starejši ljudje najverjetneje ne razmišljajo tako pogosto o nenadnih spremembah zdravstvenega stanja, ampak o postopnih, pri tem pa bi po njihovem mnenju ta storitev vendarle lahko pripomogla k zmanjšanju različnih tveganj in reševanju zdravstvenih težav med bivanjem v lastnem domu.

Zelo zanimiva je tudi ugotovitev, da anketiranci s podeželja veliko bolj verjamejo, da bi lahko storitev teleoskrbe pripomogla h kasnejšemu odhodu v dom za starejše. V primerjavi s starejšimi v mestnem okolju jih je namreč skoraj $20 \%$ več menilo, da bi ta inovativna storitev lahko pripomogla $\mathrm{k}$ podaljšanju bivanja doma. To potrjuje našo ugotovitev, da predvsem na podeželju starejši ljudje odhod v dom za starejše doživljajo kot zelo travmatično izkušnjo in imajo do nje večinoma odklonilen odnos. Pogosto jim to pomeni izhod v sili, velikokrat jo pojmujejo kot zadnje zatočišče pred smrtjo. 
Preglednica 4: Mnenje starejših ljudi glede podaljšanja bivanja v lastnem domu in kasnejšem odhodu $v$ dom za starejše zaradi teleoskrbe

Table 4: Opinions of the elderly concerning the extension of living in their homes and postponement of the institutional care due to the telecare

\begin{tabular}{|l|c|c|}
\hline \multirow{2}{*}{ Starostna skupina /kraj bivanja } & \multicolumn{2}{|c|}{$\begin{array}{c}\text { Podaljšanje bivanja doma s } \\
\text { pomočjo teleoskrbe (delež) }\end{array}$} \\
\cline { 2 - 3 } & Da & Ne \\
\hline 55-64 let & 68,6 & 31,4 \\
\hline 65-74 let & 54,8 & 45,2 \\
\hline Nad 74 let & 28,2 & 71,8 \\
\hline Mestno naselje & 38,3 & 61,7 \\
\hline Nemestno naselje & 58,0 & 42,0 \\
\hline Skupaj & 50,0 & 50,0 \\
\hline
\end{tabular}

Poleg manjšega zaupanja starejših ljudi v možnost podaljšanja bivanja doma s pomočjo teleoskrbe, se dobra tretjina vprašanih (34,5 \%) pri tej storitvi boji tudi izgube zasebnosti. Glede tega ni razlik med anketiranci glede na starost. V splošnem menijo, da bi imeli občutek, da jih ves čas nekdo opazuje:

»Hja, a da mi bodo gledali, kaj jaz v usta nesem? Prav veseli ne bi bili, kar bi videli. Saj vem, da mastnega sploh ne bi smel jesti, samo tu pa tam pa tako 'zapaše'. Pa si ne morem kaj.« (moški, 71 let)

"Tak prav 'fajn' tudi ne bi bilo, če bi ti vse pod prste gledali /.../ Saj razumem, kaj hočete povedati - da bi bilo to v moje dobro, ampak bi se pač morala navaditi." (ženska, 60 let)

»Potem bi pa tak vse vedeli o meni: kdaj grem na stranišče, kdaj vstanem, kaj jem, ali sem kaj spil. Tako kot v kakem filmu. Tako pa ja ne bi bilo za živet.« (moški, 82 let)

»Saj vem, da ste rekli, da me ne bi snemali s kamero, tako kot v tistih resničnostnih šovih na televiziji. Samo občutek bi pa imela tak. «(ženska, 58 let)

Še manj negativnih stališč $(22,4$ \%) so anketiranci izrazili glede varnosti in možnosti samostojnega življenja s pomočjo teleoskrbe, najmanj $(11,7$ \%) pa jih meni, da zaradi te storitve pri njih doma obiski sorodnikov, prijateljev, znancev ne bi bili nič manj pogosti. Med starejšimi starostniki je nekoliko več teh, ki se bojijo, da bi zaradi tega postali osamljeni (preglednica 5). To je razumljivo, saj se prav stari ljudje, ki sčasoma izgubijo svoje prijatelje, s katerimi so se družili v domačem okolju (ali zaradi njihove preselitve ali smrti), pogosto počutijo socialno izključene. Vendar pa je treba poudariti, da so razlike v deležih odgovorov med starostnimi skupinami majhne. 
Precej večja je razlika v odgovorih na to vprašanje med anketiranci po kraju bivanja. Medtem ko na podeželju starejši ljudje skoraj nimajo bojazni, da bi imeli zaradi teleoskrbe manj obiskov (tako jih meni 97,1 \%), pa je ta delež med anketiranci iz mest precej nižji. Slabo četrtino vprašanih $(23,4$ \%) je namreč strah, da bi ostali osamljeni. To ponovno potrjuje, da so na podeželju medosebni stiki tesnejši kot v mestnem okolju. Vendar pa bi bilo smiselno v nadaljnjih raziskavah nemestna naselja podrobneje razčleniti. Edina anketiranca iz nemestnih naselij, ki sta glede tega izrazila zaskrbljenost, živita namreč v gričevnatem oziroma hribovskem naselju, odmaknjenem od glavne ceste, brez drugih hiš v bližini.

Preglednica 5: Mnenje starejših ljudi o tem, ali bi zaradi teleoskrbe imeli manj obiskov in bi ostali osamljeni

Table 5: Opinions of the elderly regarding reduction of visits and possibility for isolation due to the telecare

\begin{tabular}{|l|c|c|}
\hline \multirow{2}{*}{ Starostna skupina /kraj bivanja } & \multicolumn{2}{|l|}{$\begin{array}{l}\text { Manj obiskov in večja } \\
\text { osamljenost (delež) }\end{array}$} \\
\cline { 2 - 3 } & Da & Ne \\
\hline 55-64 let & 5,7 & 94,3 \\
\hline 65-74 let & 11,9 & 88,1 \\
\hline Nad 74 let & 15,4 & 84,6 \\
\hline Mestno naselje & 23,4 & 76,6 \\
\hline Nemestno naselje & 2,9 & 97,1 \\
\hline Skupaj & 11,2 & 88,8 \\
\hline
\end{tabular}

V nadaljevanju so predstavljeni nekateri odzivi anketirancev o varnosti in možnosti samostojnega življenja ter o potencialni socialni izključenosti zaradi teleoskrbe:

„Če je res tako, kot ste povedali prej, bi me pa bilo res manj strah, da se mi kaj zgodi. Saj ne, da bi bilo kaj narobe z mano, samo nikoli ne vě̌. Kaj vse lahko slišite ... " (moški, 67 let)

»O, kak bi bilo fajn. Tak mi je že težko, ko se ta mladi tak bojijo zame, da se mi ne bi kaj naredilo, ko sem sama.« (ženska, 84 let)

»Kdo bi pa še sploh prišel k meni. Zdaj še vsaj patronažna sestra pride, pa hčerka me pride pogledat. Če bi imeli vse na računalniku, pa gor v te hribe tak nobenega ne bi bilo več.« (moški, 82 let)

»K meni še vsi vedno radi pridejo. Vsak ko ima malo 'cajta' pride naokoli. Pa spijemo kako kavo, malo se pomenimo, pa kar mine. Jaz mislim, da nobena tehnika ne more zamenjat človeške bližine. Če si z nekom rad, si pač z njim, ker hočeš biti z njim.«(ženska, 59 let) 


\section{RAZPRAVA}

Da bi ugotovili, ali so prišli do podobnih rezultatov tudi drugi, smo pregledali raziskave, pri katerih so starejše ljudi spraševali o njihovih stališčih do teleoskrbe. Analiza je pokazala, da raziskave s takšnimi rezultati obstajajo. Podrobneje si bomo pogledali naslednje tri:

V raziskavi, ki so jo v angleških mestih Barnsley, Plymouth in South Bucks izvedli Julienne Hanson in sod. (2007), je na vprašanje, ali si starejši ljudje želijo imeti teleoskrbo pri sebi doma, pritrdilno odgovorilo $64 \%$ vprašanih, pri čemer je bil najvišji delež v Barnsleyju (81 \%). Kar 98 \% jih je menilo, da bi oskrba na domu na daljavo omogočila podaljšanje bivanja doma, vsi anketiranci v Barnsleyju in $96 \%$ v South Bucksu pa bi se s pomočjo nove storitve počutili varnejše. Nekoliko več pomislekov so angleški anketiranci imeli glede nadzora, saj je le polovica (51\%) odgovorila, da jih to ne bi motilo.

Zaskrbljenost glede vdora $\mathrm{v}$ zasebnost, ki bi jo povzročila teleoskrba, je razkrilo tudi anketiranje, ki so ga izvedli Bertera in sod. (2007) v Združenih državah Amerike. Slabi dve tretjini vprašanih ne bi dovolili, da bi bivanje v njihovih domovih spremljali $\mathrm{z}$ videonapravo. Za vse druge storitve teleoskrbe pa so izrazili visoko stopnjo podpore: več kot 90-odstotno za prenos informacij o zdravstvenem stanju oskrbovancev v nadzorni center, samodejno sprožitev alarma in opominjanje za jemanje zdravil. Več kot 80-odstotno podporo je dobilo spremljanje nenavadnih sprememb v prostoru (npr. nadzor padca), spremljanje življenjskega cikla uporabnika (merjenje fizioloških funkcij) in njegovega vsakodnevnega vedenjskega vzorca ter možnost, da lahko uporabnik storitve prek spleta spremlja svoje agregirane podatke, opremljene z ustreznimi priporočili oziroma nasveti.

O zelo pozitivnih stališčih starejših ljudi do sistema teleoskrbe poročajo tudi Rahimpour in sod. (2008) za Avstralijo. Večina anketirancev, vključenih v raziskavo, je izrazila pripravljenost sprejeti to storitev, saj se jim zdi uporabna. Po njihovem bi lahko namreč pripomogla $\mathrm{k}$ samostojnemu in kakovostnemu bivanju uporabnikov $\mathrm{v}$ domačem okolju (navajajo duševni mir in udobje), izboljšanju dostopa do zdravstvenih storitev, opolnomočenju oskrbovancev glede sodelovanja pri njihovem upravljanju z zdravjem in zmanjšanju sprejemov $v$ domove za starejše (podaljšanje bivanja doma). Poudarili pa so, da odnos med uporabniki in oskrbovalci (medicinsko osebje, zdravniki in drugi) ne bi smel temeljiti le na virtualni izmenjavi informacij, ampak da bi se moral med njimi (vsaj občasno in pri bolj pomembnih zadevah) ohranjati osebni stik na podlagi obiskov, saj naj bi imelo to pozitivne psihološke učinke na zdravje in počutje ljudi.

Da je naša raziskava privedla do enakih rezultatov, torej, da so starejši ljudje v splošnem izrazili pozitivna stališča do teleoskrbe, pripisujemo dejstvu, da smo pred začetkom anketiranja sodelujočim podrobno in na razumljiv način predstavili storitev. Tudi v omenjenih raziskavah anketiranci teleoskrbe niso poznali, oziroma so zanjo le slišali, vendar niso vedeli, kaj pomeni. Zato so izpraševalci pred pričetkom zbiranja podatkov posebno pozornost namenili nazornemu opisu storitve (npr. pri angleški raziskavi v obliki scenarijev in pri avstralski s pomočjo videopredstavitve). 
Slika 3: S podaljšanjem bivanja v lastnem domu s pomočjo teleoskrbe bi lahko preložili odhod starejših v domsko oskrbo na kasnejši čas - Center starejših Trnovo (foto: B. Kerbler)

Figure 3: The extension of staying at home with the help of telecare could prolong the departure of elderly people in residential care on a later time-Centre of the elderly Trnovo (photo: B. Kerbler)

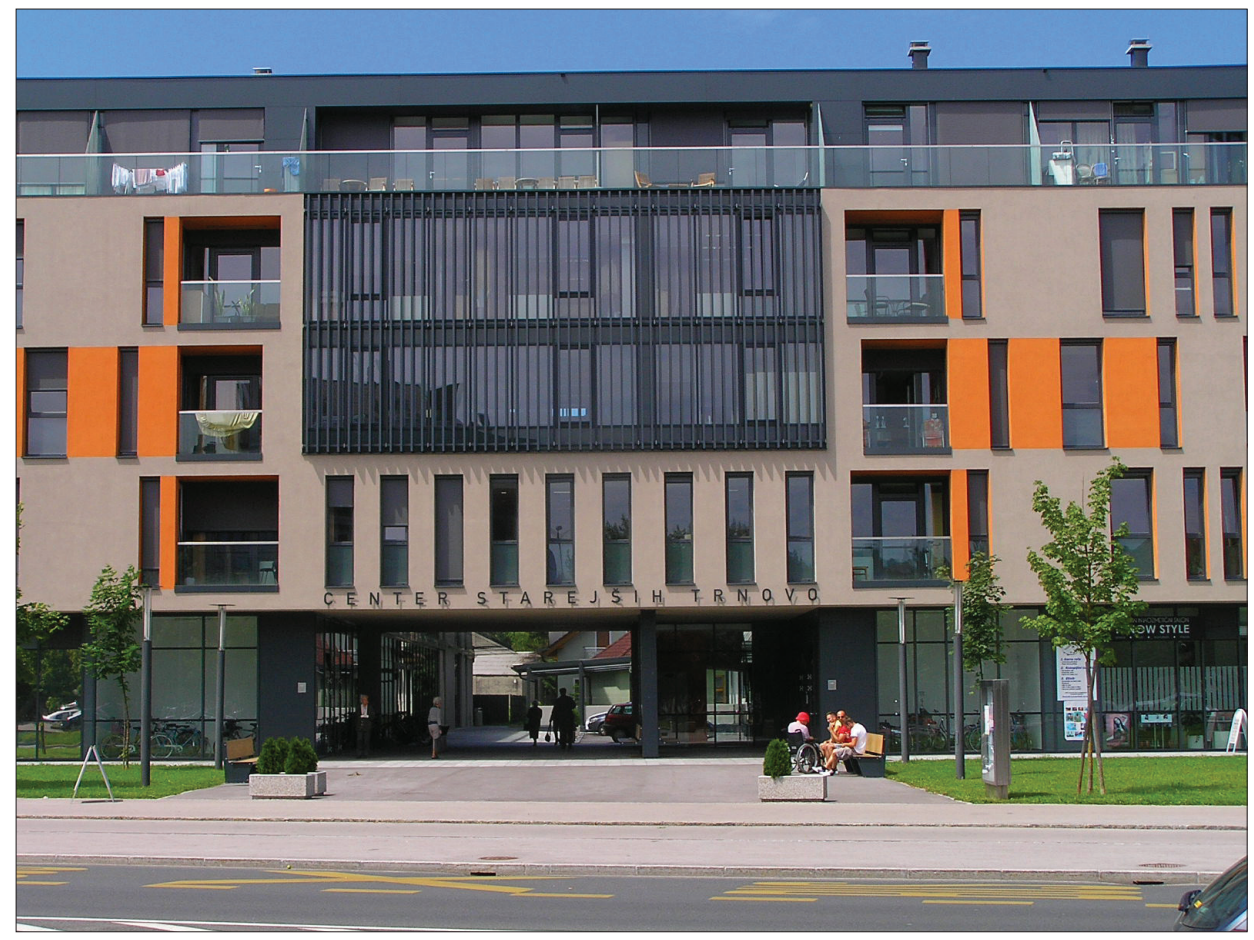

Iz tega lahko sklepamo, da je (pravilno) informiranje in ozaveščanje potencialnih uporabnikov teleoskrbe ter razumevanje delovanja in uporabnosti te storitve ključnega pomena pri njenem sprejetju med uporabniki, kar lahko bistveno pripomore k uspešni uvedbi te storitve v družbi. To potrjujejo tudi rezultati poskusov uvedbe naprednejših oblik oskrbe na daljavo na osnovi IKT na Škotskem. Tam se je namreč med letoma 2007 in 2010 za vključitev pametnih tehnologij v domače okolje, vključitev v omrežje oddaljenega nadzora in prek njega za povezavo z izvajalci oskrbe in drugih storitev odločilo kar $25 \%$ novih uporabnikov (glede na začetno stanje). Škotska vlada je pred tem zelo veliko časa in sredstev posvetila informiranju potencialnih uporabnikov o pomenu in značilnostih teleoskrbe (Joint Improvement Team, 2010). Pri tem se je izkazalo, da ima pomemben učinek na ozaveščanje in razumevanje ter posledično sprejetje inovacije izkušnja uporabnika. Kot navajajo Beale in sod. (2010), so bili podatki o zadovoljstvu uporabnikov, s katerimi so na Škotskem razpolagali pri informiranju, očitno dovolj zgovorni, da so motivirali širok krog nagovorjenih: kar 60,5 \% oskrbovancev je namreč menilo, da se je 
$\mathrm{s}$ preureditvijo doma $\mathrm{v}$ pametno okolje ter $\mathrm{z}$ vključitvijo $\mathrm{v}$ oskrbo in varstvo na daljavo kakovost njihovega življenja izboljšala. Kar 93,3 \% oskrbovancev je menilo, da so zaradi tega varnejši, 69,7 \%, da so samostojnejši, 87,2 \% pa jih je izjavilo, da imajo zato drugi družinski člani manj dela in skrbi z njimi. Škotski primer potrjuje tudi omenjena ameriška raziskava - najbolj pozitivna stališča so namreč izrazili anketiranci, ki so že imeli izkušnje s podpornimi tehnologijami.

Pravilno nagovarjanje in ozaveščanje potencialnih uporabnikov teleoskrbe je torej zelo pomembno za sprejemanje te storitve v družbi, vendar pa ni dovolj. Kot se je izkazalo v naši raziskavi, je za zagotavljanje večjega uspeha pri njenem uvajanju pomembna tudi starost potencialnih uporabnikov, predvsem pa ali živijo v mestnem ali podeželskem prostoru. Da je to eden ključnih kriterijev uvajanja, kaže tudi 'škotski’ primer poskusnih uvajanj naprednejših oblik oskrbe na daljavo, ki temeljijo na IKT (Joint Improvement Team, 2010). Na Škotskem so pilotne projekte spremljali tudi z vidika kraja bivanja starejših (mesto/podeželje), ki so bili vključeni v raziskavo.

Enak pristop so ubrali v zelo podobni raziskavi, ki so jo med letoma 2008 in 2011 izvedli v Angliji (Giordano, Clark, Goodwin, 2011). Obe študiji sta potrdili, da so potrebe pri uvajanju preučevane storitve v mestnem in podeželskem okolju različne in da se je treba na njih različno odzvati. Bi-Kun in Chung-Hung (2012) sta prav na podlagi teh spoznanj ugotavljala, kakšna so stališča starejših do teleoskrbe le na podeželskih območjih na Tajvanu. Izhajala sta iz predpostavke, da so želje starejših v nemestnih okoljih drugačne od starejših v mestih in da jih je zato treba preučiti ločeno. Ugotovila sta, da lahko tudi na podeželskih območjih, ki so bolj tradicionalna in pogosto bolj konservativna, starejši sprejmejo teleoskrbo zelo pozitivno, vendar morata biti že koncept ozaveščanja o tej storitvi in tudi njeno uvajanje v podeželsko okolje ustrezno prilagojena. Menimo, da bi bilo zato treba $v$ prihodnje v slovenskih raziskavah poseben poudarek nameniti prav temu vidiku.

Poleg ugotavljanja stališč starejših ljudi do oskrbe na daljavo s pomočjo IKT in njihova analiza glede na starost in kraj bivanja starejših, je treba poudariti, da so lahko uporabniki tovrstne storitve tudi formalni in neformalni skrbniki starejših ljudi. Da so nove tehnologije lahko v pomoč skrbnikom, potrjujejo tudi izjave svojcev, ki jih za Škotsko navajajo Beale in sod. (2010). Kar 74,3 \% skrbnikov je namreč menilo, da so zaradi njihove uporabe manj obremenjeni. V prihodnje bi bilo zato smiselno raziskavo razširiti tudi na njih, saj njihova stališča prav tako pomembno vplivajo na to, kako bo teleoskrba sprejeta, podprta in razširjena v družbi.

Da pa bi lahko teleoskrbo stvarno ovrednotili tudi skrbniki, bi morali tudi njim sistem oskrbe na domu na daljavo ustrezno predstaviti in utemeljiti, saj rezultati tujih raziskav kažejo, da so tudi stališča izvajalcev oskrbe zaradi različnih razlogov pogosto ne povsem pravilna. Omenimo samo dvoje dojemanj in zaznav teleoskrbe, ki sta lahko prisotni pri skrbnikih: strah/odpor do storitve ali pretirano navdušenje nad njo. Odpor čutijo predvsem zato, ker se jim zdi podpora bivanja starejših s pomočjo tehnologij neosebna in ker se, kot navajajo Raappana, Rauma in Melkas (2007), bojijo, da se bodo zaradi tega morali (delno ali v celoti) odpovedati svoji vlogi skrbnika, za kar se (zlasti) formalni skrbniki čutijo poklicane. Po navedbah avtorjev navedeni strah pogosto izhaja iz tega, da imajo 
skrbniki premalo znanja o uporabi tehnologij, oziroma dojemajo priučevanje za delo z njimi kot dodatno, nepotrebno in stresno obveznost. Če bi skrbniki bolje razumeli delovanje tehnologij, spoznali njihove prednosti in koristi ter se jih naučili uporabljati, bi strah pred njimi izginil in sprejeli bi jih kot del svojega življenja in dela.

Poleg odpora do tehnologij se lahko pri skrbnikih kaže tudi pretirano navdušenje nad njimi, kar prav tako onemogoča objektivno vrednotenje teleoskrbe in njeno uspešno uvajanje. Raappana, Rauma in Melkas (2007) takšno dojemanje tehnologij najpogosteje pripisujejo neformalnim skrbnikom (svojcem). Sodobni ritem in način življenja namreč vse bolj omejujeta možnosti za družinsko in domačo oskrbo starejših družinskih članov, zaradi česar se »zadnja leta ... kaže pri nas in drugod po Evropi, da glavni nosilec dosedanje oskrbe v starosti - družina - v tej svoji vlogi odpoveduje.« (Strategija varstva starejših ..., 2007, str. 9). Domači skrbniki zato od inovativnih IKT pričakujejo, da jih bodo lahko nadomestile in popolnoma razbremenile. Takšna pričakovanja so utopična in nevarna, tako za starejše ljudi, ki bi lahko dejansko postali družbeno izolirani, kot tudi za uspešnost uvajanja teleoskrbe. Razočaranje, ki bi sledilo spoznanju, da tehnologije vendarle ne morejo v celoti nadomestiti človeka, bi vodilo do odpora in širjenja negativnega mnenja družbe o oskrbi na domu na daljavo. Skrbniki bi zato morali biti natančno informirani, kakšne so dejanske zmogljivosti teleoskrbe in imeti glede njih realna pričakovanja.

\section{SKLEP}

Kot se je v raziskavi izkazalo, so starejši ljudje do IKT in inovacij, ki na njih temeljijo (npr. teleoskrba), po večini nezaupljivi in jih ne sprejemajo, če jih ne poznajo oziroma ne razumejo njihovega delovanja in učinkov. Zato tudi menimo, da za neuspešno uvedbo varovalno-alarmnega sistema v preteklih dvajsetih letih v Sloveniji niso bili krivi samo neenoten tehnični sistem, omejen geografski obseg in cena. Kriva sta bila tudi prenizka stopnja osveščenosti javnosti in neučinkovit način informiranja o tej storitvi. Kjer je bila storitev vzpostavljena in cena ni bila pretirano visoka, je bilo namreč število uporabnikov prav tako majhno, vendar pa evalvacijske študije varovalno-alarmnega sistema potrjujejo, da so bili uporabniki s storitvijo zelo zadovoljni (Hojnik-Zupanc, Ličer, Hlebec, 1996; Hlebec in sod., 2002; Zajec, 2006). Sklepamo lahko torej, da bi lahko z boljšim in učinkovitejšim informiranjem, še zlasti pa, če bi imeli potencialni uporabniki priložnost slišati pozitivna mnenja uporabnikov storitev, pripomogli k boljšemu razumevanju delovanja te storitve, zmanjšanju negativnih stališč do nje ter k njeni širši uporabi.

$\mathrm{Na}$ osnovi tega menimo, da tudi nova storitev $S O S$-gumb, ki naj bi odpravila pomanjkljivosti, ki so bile krive za neuspeh predhodne inovacije (poenotenje tehničnega sistema, cene in geografske dosegljivosti storitve), brez učinkovitega ozaveščanja potencialnih uporabnikov ne bo doživela želenega sprejetja in ražsirjenosti. To pa je slabo izhodišče za prihodnje uvajanje zahtevnejših oblik oskrbe na domu na daljavo, ki temeljijo na IKT. Vendar pa je treba poudariti, da tudi pozitivna stališča do teleoskrbe in sprejetje te storitve med uporabniki še ne zagotavljajo njene uspešne uvedbe v družbi. Za preboj te zamisli v družbi je pozitivna naravnost uporabnikov sicer zelo pomembna, vendar pa, kot ugotavlja Kerbler (2012), zajema celoten postopek uvajanja teleoskrbe kombinacijo tehnološkega 
in organizacijskega načrtovanja in vključuje poleg uporabnikov tudi druge deležnike, ki imajo različna stališča do tveganj in različne vrednostne sisteme, ki jim je treba zadostiti. Zelo pomembno je tudi upoštevati, da je uvajanje teleoskrbe različno glede na kraj bivanja starejših ljudi in se bo treba za uspešno uvedbo te storitve različno odzivati na različne potrebe starejših ljudi v mestnem in podeželskem okolju.

\section{Zahvala}

Raziskavo, v okviru katere je nastal ta prispevek, je finančno podprla Javna agencija Republike Slovenije za raziskovalno dejavnost.

\section{Viri in literatura}

Akcijski načrt za informacijske in komunikacijske tehnologije ter staranje. 2007. Bruselj, Komisija Evropskih skupnosti. URL: http://eur-lex.europa.eu/LexUriServ/LexUriServ.do?uri=COM:2007:0332:FIN:SL:PDF. (Citirano 12. 7. 2012).

Beale, S., Truman, P., Sanderson, D., Kruger, J., 2010. The initial evaluation of the Scottish telecare development program. Journal of technology in human services, 28, 1-2, str. 60-73.

Bertera, E. M., Tran, B. Q., Wuertz, E. M., Bonner, A. A, 2007. Attitudes towards health technologies for telecare and their relationship to successful aging in a communitybased older minority population. Forum on public policy: a journal of the Oxford round table, str. 1-22. URL: http://www.forumonpublicpolicy.com/archivesum07/ bertera.pdf (Citirano 6. 7. 2012).

Bi-Kun, C., Chung-Hung, T., 2012. Rural residents' perceptions and needs of telecare in Taiwan. Intelligent information and database systems. Lecture notes in computer science, 7198, str. 236-246.

Brownsell, S., Blackburn, S., Hawley, M., 2008. Evaluating the impact of 2nd and 3rd generation telecare services in older people's housing. Journal of telemedicine and telecare, 14, 1, str. 8-12.

Brownsell, S., Bradley, D., Blackburn, S., Cardinaux, F., Hawley, M. S., 2011. A systematic review of lifestyle monitoring technologies. Journal of telemedicine and telecare, 17, 4, str. 185-189.

Cheverst, K., Clarke, K., Dewsbury, G., Hemmings, T., Hughes, J., Rouncefield, M., 2003. Design with care: technology, disability and the home. V: Harper, R. (ur.). Inside the smart home, 2. del. London, Springer, str. 163-179.

Czaja, S. J., Charness, N., Fisk, A. D., Hertzog, C., Nair, S. N., Rogers, W. A., Sharit, J., 2006. Factors predicting the use of technology: finding from the Center for research and education on aging and technology enhancement (CREATE). Psychology and aging, 21, 2, str. 333-352.

Demiris, G., Rantz, M., Aud, M., Marek, K., Tyrer, H., Skubic, M., Hussam, A., 2004. Older adults' attitudes towards and perceptions of 'smart home' technologies: a pilot study. Medical informatics and the internet in medicine, 29, 2, str. 87-94. 
Doughty, K., Cameron, K., Garner, P., 1996. Three generations of telecare of the elderly. Journal of telemedicine and telecare, 2, 2, str. 71-80.

Fisk, M. J., 2003. Social alarms to telecare. Older people's services in transition. Chicago, The University of Chicago Press Books, 304 str.

Giordano, R., Clark, M., Goodwin, N., 2011. Perspectives on telehealth and telecare. Learning from the 12 Whole System Demonstrator Action Network (WSDAN) sites. London, WSD Action Network, 42 str. URL: http://www.kingsfund.org.uk/sites/files/ kf/Perspectives-telehealth-telecare-wsdan-paper.pdf (Citirano 13. 11. 2013).

Glueckauf, R. L., Ketterson, T. U., 2004. Telehealth interventions for individuals with chronic illness. Research review and implications for practice. Professional psychology: research and practice, 35, 6, str. 615-627.

Hanson, V. L., 2001. Web access for elderly citizens. WUAUC'01 Proceedings of the 2001 EC/NSF workshop on universal accessibility of ubiquitous computing: providing for the elderly, str. 14-18.

Hanson, J., Percival, J., 2006. Differing perspectives on telecare: an attitudinal survey of older people, professional care workers and informal carers. V: Langdon, C. J. (ur.). Designing accessible technology. London, str. 215-226. URL: http://discovery.ucl. ac.uk/3834/1/3834.pdf (Citirano 5. 7. 2012).

Hanson, J., Percival, J., Aldred, H., Brownsell, S., Hawley, M., 2007. Attitudes to telecare among older people, professional care workers and informal carers: a preventative strategy or crisis management? Universal access in the information society, 6, 2, str. 193-205. URL: http://discovery.ucl.ac.uk/3845/1/3845.pdf (Citirano 12. 7. 2012).

Hlebec, V., Ličer, N., Bitenc, K., Nagode, M., 2002. Evalvacija 10-letne uporabe alarmnega sistema kot sredstva večje samostojnosti starostnikov. Zdravstveno varstvo, 41, 3-6, str. 153-159.

Hojnik-Zupanc, I., Ličer, N., Hlebec, V., 1996. Varovalni alarmni sistem kot socialna inovacija v slovenskem prostoru. Zdravstveno varstvo, 35, 9-10, str. 289-294.

Jepsen, M., Leschke, K., 2008. Social protection and the social reality of Europe. V: Jepsen, M. (ur.): Benchmarking working Europe 2008. Bruselj. URL: http://www.etui.org/Publications2/Books/Benchmarking-Working-Europe-2008 (Citirano 12. 7. 2012).

Joint Improvement Team, 2010. An assessment of the development of telecare in Scotland 2006-2010. URL: http://www.jitscotland.org.uk/downloads/1295965164-Development_of_Telecare1.pdf(Citirano 12. 7.2012).

Kerbler, B., 2012. Ageing at home with the help of information and communication technologies. Acta Geographica Slovenica, 52, 1, str. 165-188.

Lee, S. Y., Phippen, A., 2006. The state of elderly in ICT adoption at rural areas. V: Dowland, P. S., Furnell, S. M. (ur.). Advances in networks, computing and communications, 3, str. 241-250.

Levy, S., Jack, N., Bradley, D., Morison, M., Swanston, M., 2003. Perspectives on telecare: the client view. Journal of telemendicine and telecare, 9, 3, str. 156-160.

Marquié, J. C., Jourdan-Boddaert, L., Huet, N., 2002. Do older adults underestimate their actual computer knowledge? Behaviour \& information technology, 21, 1, str. 273-280. 
Mestna naselja v Republiki Sloveniji 2003. 2004. Ljubljana, Statistični urad Republike Slovenije, 140 str. URL: http://www.stat.si/doc/pub/mestna_naselja_slo_03.pdf (Citirano 15. 7. 2012).

Pecora, F., Cesta, A., 2007. DCOP for smart homes: a case study. Computational intelligence, 23, 4, str. 395-419.

Pečjak, V., 1998. Psihologija tretjega življenjskega obdobja. Ljubljana, Znanstveni inštitut Filozofske fakultete, 201 str.

Percival, J., Hanson, J., 2006. Big brother or brave new world? Telecare and its implications for older people's independence and social inclusion. Critical social policy, 26, 4, str. 888-909.

Projekcije prebivalstva EUROPOP2010 za Slovenijo po spolu in starosti, 2010-2060. 2011. Ljubljana, Statistični urad Republike Slovenije. URL: http://pxweb.stat. si/pxweb/Database/Dem_soc/05_prebivalstvo/45_projekcije/10_05U30_europop_2010/10_05U30_europop_2010.asp (Citirano 13.11.2013).

Projekcije prebivalstva za Slovenijo, 2010-2060 - končni podatki. 2011. Ljubljana, Statistični urad Republike Slovenije. URL: http:/www.stat.si/novica_prikazi. aspx?id=3989 (Citirano 13. 11. 2013).

Raappana, A., Rauma, M., Melkas, H., 2007. Impact of safety alarm systems on care personnel. Gerontechnology, 6, 2, str. 112-117.

Rahimpour, M., Lovell, N. H., Celler, B. G., McCormick, J., 2008. Patients’ perceptions of a home telecare system. International journal of medical informatics, 77, str. 486-498.

Redford, L. J., Whitten, P., 1997. Ensuring access to care in rural areas: the role of communication technology. Generations, 21, 3, str. 19-24.

Remagnino, P., Shapiro, D., 2007. Artificial intelligence methods for ambient intelligence. Computational intelligence, 23, 4, str. 393-394.

Richardson, M., 2006. Interruption events and sensemaking processes: a narrative analysis of older people's relationships with computers. Doctor thesis. University of Waikato, 288 str. URL: http://researchcommons.waikato.ac.nz/bitstream/handle/10289/2626/ thesis.pdf? sequence=2 (Citirano 5. 7. 2012).

Richardson, M., Weaver, C. K., Zorn, T. E., 2005. 'Getting on': older New Zealanders' perceptions of computing. New media \& society, 7, 2, str. 219-245.

Rogers, E. M., 1962. Diffusion of innovations, 6. izdaja. London, Free Press, 367 str.

Saranummi, N., Korhonen, I., Kivisaari, S., Ahjopalo, H., 2006. A framework for developing distributed ICT applications for health, distributed diagnosis and home healthcare. 1st transdisciplinary conference on distributed diagnosis and home healthcare, str. 137-143.

Sixsmith, A., Sixsmith, J., 2000. Smart care technologies: meeting whose needs? Journal of telemedicine and telecare, 6, suppl. 1, str. 190-192.

Smolej, S., Nagode, M., Jakob Krejan, P., 2010. Izvajanje pomoči na domu: analiza stanja v letu 2009. Ljubljana, Inštitut Republike Slovenije za socialno varstvo, 53 str.

Sponselee, A., Schouten, B., Bouwhuis, D., Willems, C., 2008. Smart home technology for the elderly: perceptions of multidisciplinary stakeholders. Communications in computer and information science, 11, str. 311-326. 
Statistični letopis 2012. 2012. Ljubljana, Statistični urad Republike Slovenije, 589 str. URL: http://www.stat.si/letopis/letopisprvastran.aspx (Citirano 13. 11. 2013).

Strategija varstva starejših do leta 2010 - solidarnost, sožitje in kakovostno staranje prebivalstva. 2007. Ljubljana, Ministrstvo za delo, družino in socialne zadeve, 45 str. URL: http:/www.mddsz.gov.si/fileadmin/mddsz.gov.si/pageuploads/dokumenti pdf/strategija_varstva_starejsih_splet_041006.pdf(Citirano 15. 7. 2013).

Tetley, J., Hanson, E., Clarke, A., 2001. Older people, telematics and care. V: Warnes,

A. M., Warren, L., Nolan, M. (ur.). Care services for later life: transformations and critiques. London, Jessica Kingsley Publishers, str. 243-258.

The 2012 ageing report: underlying assumptions and projection methodologies. 2011.

European economy, 4. URL: http://ec.europa.eu/economy_finance/publications/european_economy/2011/pdf/ee-2011-4_en.pdf (Citirano 13. 11. 2013).

Wylde, M., Valins, M. S., 1996. The impact of technology. V: Valins, M. S., Salter, D. (ur.): Futurecare: new directions in planning health and care environments. Oxford, str. 15-24.

Zajec, K., 2006. Varovanje na daljavo v Sloveniji - razvoj in perspektive. Diplomsko delo. Ljubljana, Fakulteta za socialno delo, 82 str.

\section{ATTITUDES OF THE ELDERLYTOWARDS A REMOTE HOME CARE}

\section{Summary}

Remote home care (telecare) enables the elderly to remain in their home environment as long as possible, where they would be capable of leading their lives as independently as possible with the best possible quality of life. However, the findings of various authors suggest that elderly people have mostly negative attitudes towards remote home care. One of the perceptions that often deter elderly people is that living in an intelligent environment is too automated. They often perceive technology as a replacement for personal forms of care, protection and communication, which could result in a loss of social interaction and isolation. Elderly people are also 'technophobic', therefore, they are afraid of innovations and new technologies. Often have a lack of confidence, because they doubt to their own capabilities due to sensory and cognitive deficiencies. Further, the elderly are more conservative and do not want to have their lives and lifestyles changed. They are afraid of losing the privacy and they suffer from the so-called big brother syndrome - the feeling that they are controlled and watched.

To determine what are the attitudes towards remote home care of the elderly people in Slovenia, a survey was conducted, the results of which are discussed in this article. The assumption is based on the findings of various authors that elderly people have mostly negative attitude towards telecare.

The research was conducted in the first half of 2012. Data were collected through face-to-face interviews and the research sample consisted of 116 people aged 55 years or more. In urban areas lived 47 or $40.5 \%$ of the respondents and in non-urban 69 or $59.5 \%$. Before proceeding with the interviews, telecare was explained in the simplest and understandable 
way to all respondents. For this purpose five short 'scenarios' have been prepared, in which through the events of everyday life the operation and usefulness of this service was presented, as well as the role of users in relation to technology in home environment.

Results of a survey have shown that elderly people in Slovenia have positive attitudes towards telecare, which is contrary to our assumption. $78.4 \%$ of the respondents replied that they want to have such service in their own homes, even if they do not find positive all characteristics of telecare. Most of these were 'younger' elderly people (85.7\%), aged 55 to 64 years. In the higher age groups, the share of the respondents with positive attitudes declines, but is, nevertheless, still high (71.8\%).

Depending on the place of residence there are more elderly in non-urban areas who want telecare service. This suggests that elderly people in rural areas have strong emotional ties to the home environment. Due to this traditional ties of close interpersonal relationships and often dismissive attitudes towards the urban environment, elderly in rural areas do not want to be institutionalized, but want to stay as long as possible in the place where they live. Therefore, ageing at home provided by telecare would be a great solution for them.

However, further analysis revealed that elderly people still have some concerns about the remote home care system. Half of them do not believe that the system enables extension of living in their own homes and postponing institutional care. In addition to this, one third of the respondents $(34.5 \%)$ is afraid of losing the privacy. Less negative opinions $(22.4 \%)$ the respondents expressed about the safety which would be provided by telecare. The least $(11.7 \%)$ of them believe that such service could reduce visits of relatives, friends and acquaintances in their homes.

The reason that elderly people have, in generally, expressed positive attitudes towards telecare is the result of the fact that before the survey the services were presented in detail in the most comprehensive manner to all respondents. According to our opinion, unsuccessful implementation of safety alarm system in Slovenia in the last twenty years was not only due to the non-unified technical system, limited geographical scope and price, but mainly because of the low level of public awareness and inefficient information campaign about this service.

We can conclude that better and more effective information and, in particular, if the potential users would have the opportunity to hear positive feedback from those who already use the service, would help to improve understanding how these services operate, which would reduce the negative attitudes among the elderly. Raising awareness of potential users is, therefore, crucial for acceptance of telecare in a society. In introducing the remote home care, it is also very important recognition that the respond to the needs of the elderly in urban and rural areas should be different.

(Translated by the author) 